\title{
So, and if it is not congenital adrenal hyperplasia? Addressing an undiagnosed case of genital ambiguity
}

\section{Reinaldo Luna de Omena Filho}

Alagoas State University of Health Sciences: Universidade Estadual de Ciencias da Saude de Alagoas

\section{Reginaldo José Petroli}

Federal University of Alagoas: Universidade Federal de Alagoas

\section{Fernanda Caroline Soardi}

State University of Campinas: Universidade Estadual de Campinas

\section{Débora de Paula Michelatto}

Federal University of Alagoas: Universidade Federal de Alagoas

\section{Taís Nitsch Mazzola}

State University of Campinas: Universidade Estadual de Campinas

\section{Helena Fabbri-Scallet}

State University of Campinas: Universidade Estadual de Campinas

\section{Maricilda Palandi de Mello}

State University of Campinas: Universidade Estadual de Campinas

\section{Susane Vasconcelos Zanotti}

Federal University of Alagoas: Universidade Federal de Alagoas

Ida Cristina Gubert

Federal University of Parana: Universidade Federal do Parana

Isabella Monlleo ( $\boldsymbol{Q}$ isabella.monlleo@gmail.com )

Universidade Federal de Alagoas https://orcid.org/0000-0003-0992-2151

\section{Case report}

Keywords: rare disease, ambiguous genitalia, HSD17B3 deficiency, novel variant, case report

Posted Date: September 7th, 2021

DOI: https://doi.org/10.21203/rs.3.rs-869034/v1

License: (1) (1) This work is licensed under a Creative Commons Attribution 4.0 International License. Read Full License 


\section{Abstract}

The Congenital Adrenal Hyperplasia due to 21 hydroxylase deficiency is the most common cause of genital ambiguity in persons with $X X$ sexual chromosomes. Genital ambiguity among persons with $X Y$ sexual chromosomes comprises diverse and rare etiologies. The deficiency of 17-beta-hydroxysteroid dehydrogenase type 3 enzyme (HSD17B3) is a rare autosomal recessive disorder due to functionally altered variants of the HSD17B3 gene. In this disorder/difference of sex development, the conversion of androstenedione into testosterone is impaired. The appearance of external genitalia of $46, X Y$ individuals varies from typically male to almost female. We report on a child presenting severe ambiguous genitalia. Due to access constraints, specialized care did not start until the child was 10 months old. Parents are consanguineous and were born in an area of high isonymy that is a cluster for rare recessive diseases. A new homozygous missense variant c.785G > T was found in exon 10 of the HSD17B3 gene. Researchersclinicians and researchers-researchers collaborative efforts to elucidate the genetic basis of this disease were critical since this etiologic investigation is not available through the public health system. This case exemplifies the families' pilgrimage in cases of genital ambiguity due to a rare genetic condition. Recognizing the etiology was the baseline to provide information on prognosis and treatment options, and to shelter family and child doubts and hopes in order to better support their decisions.

\section{Background}

Rare diseases are always challenging for patients, their families and health professionals. When it comes to those that affect sexual development/differentiation, patients face other still complex vulnerabilities such as seeing himself/herself as different from the others, being targets of bullying in school age, and finding difficulties in understanding the situation [1].

The Congenital Adrenal Hyperplasia due to 21 hydroxylase deficiency is the most common cause of genital ambiguity in persons with $\mathrm{XX}$ sexual chromosomes. Genital ambiguity among persons with $\mathrm{XY}$ sexual chromosomes comprises diverse and rare etiologies [2].

The deficiency of 17ß-hydroxysteroid dehydrogenase type 3 (HSD17B3; OMIM \# 264300) is a good example. This 46,XY disorder/difference of sex development (DSD) is due to disruption of HSD17B3 gene $(O M I M * 605573)$ that impairs the conversion of androstenedione into testosterone mediated by the HSD17B3 enzyme. Inherited as an autosomal recessive condition, it shows a wide prevalence variation, ranging from 1:100-300 in Gaza Strip, where consanguineous marriages are frequent, to 1:147,000 in the Netherlands [3-7].

In cases of HSD17B3 deficiency, the external genitalia may range from male to almost female appearance including several degrees of ambiguity. Testes usually are in the inguinal canal or in the labioscrotal folds. Wolffian derivates are present, suggesting that low testosterone concentration is sufficient for internal male genitalia differentiation [5-8]. 
The recognition of genital ambiguity facilitates early diagnosis in childhood. On the other hand, individuals presenting minor genital changes and reared as girls may not be diagnosed until adolescence or adulthood. At this stage, primary amenorrhea and virilization of external genitalia may arise due to peripheral testosterone conversion [6,9-11]. At any stage of life, this is a stressful situation that should be addressed carefully by an experienced multidisciplinary team in a patient-centered manner.

\section{Case Report}

A 10-month-old child, assigned as female at birth, resident in the countryside of the Northeast region of Brazil, was referred to our team for genetic assessment due to genital ambiguity. Pregnancy and delivery were uneventful. Parents reported a clitoris enlargement and gonadal descent when the child was 30 days old. Afterward, they decided to rear him as a boy despite the maintenance of female legal sex. The patient is the second child in a consanguineous marriage (double first cousins once removed), with no familial recurrence of the disorder in the family (Fig. 1).

Upon physical examination the genital ambiguity was Quigley's type 4 [12]. There was a phallus measuring $25 \mathrm{~mm} \times 10 \mathrm{~mm}$, palpable gonads at labioscrotal folds $\left(1 \mathrm{~cm}^{3}\right.$ left-sided and $0.5 \mathrm{~cm}^{3}$ rightsided), and an urogenital sinus with a perineal opening (Fig. 2). The karyotype of peripheral lymphocytes was 46,XY. Basal FSH and LH levels were normal while those for testosterone were low. Abdominal ultrasound showed no Mullerian derivates.

The etiologic investigation included androgen receptor $(R A-O M I M * 313700)$, steroid 5a-reductase 2 (SRD5A2 - OMIM * 607306), nuclear receptor subfamily 5 group A member 1 (NR5A1-OMIM * 184757), and $H S D 17 B 3$ genes sequencing, and predictive analyzes (Additional file 1).

Sequencing studies showed a novel homozygous c.785G > T nucleotide change in exon 10 of the HSD17B3 gene (Additional file 2), which was inherited from both heterozygous parents. The c.785G > T substitution leads to the replacement of glycine by valine in residue 262 (p.Gly262Val).

Predictive analyzes were compatible with a damaging missense variant and indicated that valine 262 destabilizes the protein structure. Glycine 262 is a highly conserved residue (Additional file 3 ) and the comparison between them did not reveal changes on the protein internal contacts (Additional file 4).

\section{Discussion And Conclusion}

\subsection{Clinical issues that impact on the family}

The main cause of genital ambiguity is congenital adrenal hyperplasia, which can be lethal in the neonatal period if not diagnosed and timely treated. In this sense, neonatal screening represents a significant improvement in health care $[2,13]$. 
On the other hand, genital ambiguity due to non-life-threatening etiologies is also an urgent situation because of the devastating impact it can have on the family and throughout the life of the person with this clinical condition. Although these children may be recognized at birth, they are not usually diagnosed promptly, either because of the lack of knowledge of health professionals or the unavailability of genetic tests. The last may comprise diverse and complex molecular methods from peripheral karyotype to exome sequencing [14-19]. For many persons living in middle and low income countries, a simple karyotype may be unreachable.

The 46, XY DSD group is particularly challenging since different diseases share the same clinical features. This is the case of HSD17B3 deficiency that overlaps with other conditions that affect both the androgens synthesis or action. In the clinical setting, it is not always easy to establish a specific diagnosis since ambiguous genitalia with no Mullerian structures is a common feature in DSD, and basal hormonal probes are age-dependent. In cases of HSD17B3 deficiency, a testosterone/androstenedione ratio lower than 0.8 has shown a $100 \%$ diagnosis sensitivity in children up to six months old, illustrating the importance of early diagnosis. In any case, the molecular analysis of sex-related developmental genes is a critical tool not only for diagnostic purposes but also for genetic counseling $[6,9-11]$.

It is noteworthy that although parents had noticed the genital ambiguity when the child was 30 days old, our patient was ten months old at first genetic assessment. The time elapsed illustrates the difficulty of accessing specialized care through the Brazilian Unified Health System (SUS). Some of the reasons that may explain this situation are practitioners' lack of knowledge on rare diseases, incoordination between the different levels of the SUS, shortfall of geneticists, and economical constraints [14].

The SUS assists around $80 \%$ of the Brazilian population which is an important achievement considering Brazil's extension and complexity. Significant improvement in the care of persons living with genetic disorders was gained since the implementation of the national policy on rare diseases in 2014. Currently, the country has 17 rare diseases enabled services randomly distributed in the national territory.

Furthermore, the unavailability of genetic tests, including those for DSD, remains a bottleneck [15-18].

Our team is a multidisciplinary and voluntary group that provides open door care to DSD patients at the University Hospital from the Federal University of Alagoas. The genetic investigation is performed as a research protocol mainly in partnership with colleagues from the State University of Campinas. This collaboration eventually allowed us to investigate DSD etiology in this family.

Three years have elapsed from the first consultation with us to the conclusion of genetic tests due to personnel and financial constraints. Meanwhile, the family gave up the follow up restarting it when the child was six years old. Although they continue rearing the child as a boy, they have not decided on treatment and legal sex yet, which remains as female. Currently, they are engaged with our team psychologist.

\subsection{Molecular and genetic studies provision}


The variant c.785G > T herein described causes the replacement of glycine by valine in the residue 262 of HSD17B3 as checked against The Human Gene Mutation Database [20], ClinVar [21], Genome Aggregation Database [22], and Brazilian Genomic Variants [23]. As far as we know, this variant has never been reported before.

Glycine 262 is a conserved residue. Its side chains contain hydrogen, which provides conformational flexibility, while valine is a $\mathrm{C} \beta$ branched and hydrophobic amino acid with less conformational flexibility [24]. Therefore, the variant valine 262 can affect the protein due to the amino acid structure. The alignment between the wild-type and the variant protein (Additional file 4) shows that the amino acid change could affect the protein structure, although the internal contacts have not been affected.

Upon these predictive analyzes, we hypothesize that the p.Gly262Val variant has led to a decrease in the HSD17B3 activity. As a consequence, testosterone synthesis was lowered to an insufficient rate to ensure our patients' complete genital masculinization. Thus, we suggest the p.Gly262Val variant is pathogenic, although in vitro protein function studies should be carried out in order to validate these data.

The heterozygosis of this variant was found in both parents, who are double first cousins once removed as shown in Fig. 1. Consanguineous unions (those between persons with a common ancestor) and endogamy (union between persons belonging to the same community or social/ethnic group) are wellestablished risk factors for rare genetic conditions. These relationships have been studied for years in Brazil, with evidence of a significant impact in the Northeast region. By the end of 1990, the analysis of shared surnames (isonymy) arose as a powerful method to investigate migration, miscegenation, and isolation. Such population behaviors may be additional factors favoring the occurrence of rare diseases [25-29].

Our patient's parents, as well as those of another case of HSD17B3 deficiency reported by the authors a few years ago [30], are consanguineous. Both families come from an area with the highest rate of isonymy in Brazil [29].

The case presented here exemplifies how challenging the care of persons with rare DSD can be. From the patients' perspective the first vulnerability lies in the search for the correct and early diagnosis, which may not be reached before a pilgrimage through specialists and health services, the amount of analysis and costs of all kinds - time, emotional, and why not, financial [31, 32].

Additionally, patients and families need accurate information on diagnosis and prognosis to make complex decisions on rearing sex, and clinical and surgical treatment [33-35]. These challenges are even higher in countries with abyssal inequities, such as Brazil, where patients' pilgrimage is usually arduous.

In this case, the diagnosis of HSD17B3 deficiency was reached when the child was four-years-old as a result of a collaborative effort of researchers involved with DSD investigations. Nonetheless, the time elapsed has left its mark. The child is already six and is being reared as a boy, however, he is beginning to perceive differences between himself and other children. This situation is making the family's suffering a 
continuous cycle and should be put on the table when discussing the wide impacts of undiagnosed rare diseases.

From a genetic viewpoint, the novel homozygous variant c.785G > T of the HSD17B3 gene widen the molecular knowledge on this rare 46,XY DSD. Family pedigree alongside data on consanguinity and isonymy in Brazil corroborates the importance of our region as a cluster for autosomal recessive diseases in the country.

\section{Abbreviations}

DSD

disorder/difference of sex development

HSD17B3

17-beta-hydroxysteroid dehydrogenase type 3

NR5A1

nuclear receptor subfamily 5 group A member 1

RA

androgen receptor

SRD5A2

steroid 5a-reductase 2

SUS

Brazilian Unified Health System

\section{Declarations}

\section{Ethics approval and consent to participate}

Participant's mother provided written informed consent and the father's consent was verbal. The informed consent approved by the Research Ethics Committee of the Federal University of Alagoas (\# 19144013.5.0000.5013 - Comitê de Ética em Pesquisa of the Universidade Federal de Alagoas) states that one of the aims of the study is to reach the diagnosis to provide treatment and genetic counseling for the participant family. Since this case refers to an autosomal recessive disease, the study of genetic variants in both parents is an inherent part of the diagnostic investigation. Without this, genetic counseling is not possible.

According to Brazilian law, in the case of minors (individuals younger than the age of 18), consent for participation in research protocols must be given by one of the parents or legal guardians. In line with this regulation, it was obtained the mother's written consent. By consenting to the participation of the child, the parents agree to the investigation of the causative variant in their genetic material.

\section{Consent for publication}


Participant's mother provided written informed consent and the father's consent was verbal following Brazilian regulations above mentioned. The consent clearly states that information will be used for scientific purposes, and no personal information will be disclosed.

\section{Availability of data and materials}

The datasets generated and analyzed during the current study are not publicly available due individual privacy issues, however they may be available from the corresponding author on reasonable request.

\section{Competing interests}

The authors declare that they have no competing interests.

\section{Funding}

None.

\section{Authors' contributions}

RLOF, RJP and ILM: study conception and design; collection, analysis and interpretation of data; manuscript drafting and review, patients' clinical review and sampling. FCS, DPM, TNM, HFS and MPM: patients' genetic testing. SVZ and ICG: manuscript drafting and review. All authors read and approved the final manuscript.

\section{Acknowledgments}

Authors thank the patient's family for enrolling the study, the laboratory personnel from Human Cytogenetic Lab of the State University of Health Sciences of Alagoas, specifically to Diogo Nascimento and Michel Alves, for technical support, and to the pediatric resident of the University Hospital of the Federal University of Alagoas, Dr. Marianne Danielle de Araújo.

\section{Authors' information}

RLOF is a master degree student of the Programa de Pós-graduação em Ciências da Saúde at the Instituto de Ciências Biológicas e da Saúde da Universidade Federal de Alagoas/Coordenação de Aperfeiçoamento de Pessoal de Nível Superior - CAPES.

\section{References}

1. InterACT HR. Human Rights Watch (Organization). "I Want to Be Like Nature Made Me": Medically Unnecessary Surgeries on Intersex Children in the US. [Internet]. 2017. Available from: https://www.hrw.org/report/2017/07/25/i-want-be-nature-made-me/medically-unnecessarysurgeries-intersex-children-us. 
2. Hughes IA. Disorders of sex development: a new definition and classification. Best Pract Res Clin Endocrinol Metab. 2008;22:119-34.

3. Rösler A. Steroid 17ß-hydroxysteroid dehydrogenase deficiency in man: An inherited form of male pseudohermaphroditism. J Steroid Biochem Mol Biol [Internet]. 1992;43:989-1002. Available from: http://www.ncbi.nlm.nih.gov/pubmed/8626842.

4. Boehmer AL, Brinkmann AO, Sandkuijl LA, Halley DJ, Niermeijer MF, Andersson S, et al. 17Betahydroxysteroid dehydrogenase-3 deficiency: diagnosis, phenotypic variability, population genetics, and worldwide distribution of ancient and de novo mutations. J Clin Endocrinol Metab [Internet]. 1999 [cited 2019 Jun 19];84:4713-21. Available from: https://academic.oup.com/jcem/articleabstract/84/12/4713/2864788.

5. George MM, New MI, Ten S, Sultan C, Bhangoo A. The clinical and molecular heterogeneity of 17ßHSD-3 enzyme deficiency. Horm Res Paediatr [Internet]. 2010;74:229-40. Available from: http://www.ncbi.nlm.nih.gov/pubmed/20689261.

6. Mendonca BB, Gomes NL, Costa EMF, Inacio M, Martin RM, Nishi MY, et al. 46,XY disorder of sex development (DSD) due to 17ß-hydroxysteroid dehydrogenase type 3 deficiency. J Steroid Biochem Mol Biol [Internet]. Elsevier Ltd; 2017;165:79-85. Available from: http://dx.doi.org/10.1016/j.jsbmb.2016.05.002.

7. Folsom LJ, Hjaige M, Liu J, Eugster EA, Auchus RJ. Germ cell neoplasia in situ complicating 17ßhydroxysteroid dehydrogenase type 3 deficiency. Mol Cell Endocrinol [Internet]. Elsevier; 2019;489:38. Available from: https://doi.org/10.1016/j.mce.2018.11.014.

8. Andersson S, Geissler WM, Wu L, Davis DL, Grumbach MM, New Ml, et al. Molecular genetics and pathophysiology of 17 beta-hydroxysteroid dehydrogenase 3 deficiency. J Clin Endocrinol Metab [Internet]. 1996;81:130-6. Available from: http://www.ncbi.nlm.nih.gov/pubmed/8550739.

9. Felicia M, Cavallo L. 17ß-Hydroxysteroid Dehydrogenase Type 3 Deficiency: Diagnosis, Phenotypic Variability and Molecular Findings. Steroids - Basic Sci [Internet]. InTech; 2012. Available from: http://www.intechopen.com/books/steroids-basic-science/17-hydroxysteroid-dehydrogenase-type-3deficiency-diagnosis-phenotypic-variability-and-molecular-fin.

10. Bertelloni S, Balsamo A, Giordani L, Fischetto R, Russo G, Delvecchio M, et al. 17beta-Hydroxysteroid dehydrogenase-3 deficiency: from pregnancy to adolescence. J Endocrinol Invest [Internet]. 2009;32:666-70. Available from: http://link.springer.com/10.1007/BF03345738.

11. Sagsak E, Aycan Z, Savas-Erdeve S, Keskin M, Cetinkaya S, Karaer K. 17ßHSD-3 enzyme deficiency due to novel mutations in the HSD17B3 gene diagnosed in a neonate. J Pediatr Endocrinol Metab [Internet]. 2015;28:957-9. Available from: https://www.degruyter.com/view/j/jpem.2015.28.issue-78/jpem-2014-0354/jpem-2014-0354.xml.

12. Quigley CA, De Bellis A, Marschke KB, El-Awady MK, Wilson EM, French FS. Androgen receptor defects: historical, clinical, and molecular perspectives. Endocr Rev [Internet]. 1995;16:271-321. Available from: https://academic.oup.com/edrv/article-lookup/doi/10.1210/edrv-16-3-271. 
13. White PC, Speiser PW. Congenital adrenal hyperplasia due to 21-hydroxylase deficiency. Endocr Rev [Internet]. 2000;21:245-91. Available from: https://academic.oup.com/edrv/article/21/3/245/2423831.

14. Zanotti SV, da Silva Xavier HV. Atenção à saúde de pacientes com ambiguidade genital. Arq Bras Psicol [Internet]. 2011;63:82-91. Available from: http://pepsic.bvsalud.org/scielo.php? script=sci_arttext\&pid=S1809-52672011000200009\&lng=pt\&tlng=pt.

15. Federhen A, Pinto Vairo F, Vanzella C, Paula de Boer A, Baldo G, Giugliani R. Pesquisa clínica e doenças raras: a situação no Brasil. J Bras Econ Saúde [Internet]. 2014;17-23. Available from: http://www.jbes.com.br/images/edicao-especial2014/jbes-especial03.pdf.

16. Ministério da Saúde [Internet]. [cited 2020 Dec 23]. Available from: http://bvsms.saude.gov.br/bvs/saudelegis/gm/2014/prt0199_30_01_2014.html.

17. Passos-Bueno MR, Bertola D, Horovitz DDG, de Faria Ferraz VE, Brito LA. Genetics and genomics in Brazil: a promising future. Mol Genet genomic Med [Internet]. 2014;2:280-91. Available from: http://www.ncbi.nlm.nih.gov/pubmed/25077170.

18. Doenças raras [Internet]. [cited 2020 Oct 15]. Available from: https://antigo.saude.gov.br/saude-de-az/doencas-raras.

19. Baxter RM, Vilain E. Translational genetics for diagnosis of human disorders of sex development. Annu Rev Genomics Hum Genet [Internet]. 2013;14:371-92. Available from: http://www.ncbi.nlm.nih.gov/pubmed/23875799.

20. HGMD® mutation result [Internet]. [cited 2020 Sep 22]. Available from: http://www.hgmd.cf.ac.uk/ac/all.php.

21. HSD17B3[gene] -. ClinVar - NCBI [Internet]. [cited 2020 Jul 9]. Available from: https://www.ncbi.nlm.nih.gov/clinvar/?term=HSD17B3\%5Bgene\%5D.

22. HSD17B3 | gnomAD [Internet]. [cited 2020 Jan 25]. Available from: https://gnomad.broadinstitute.org/gene/ENSG00000130948?dataset=gnomad_r2_1.

23. ABraOM. Brazilian genomic variants [Internet]. [cited 2020 Sep 22]. Available from: http://abraom.ib.usp.br/search.php.

24. Betts MJ, Russell RB. Amino-Acid Properties and Consequences of Substitutions. Bioinforma Genet [Internet]. Chichester, UK: John Wiley \& Sons, Ltd; 2007. p. 311-42. Available from: http://doi.wiley.com/10.1002/9780470059180.ch13.

25. Cardoso GC, de Oliveira MZ, Paixão-Côrtes VR, Castilla EE, Schuler-Faccini L. Clusters of genetic diseases in Brazil. J Community Genet [Internet]. Journal of Community Genetics; 2019;10:121-8. Available from: http://www.ncbi.nlm.nih.gov/pubmed/29860645.

26. Freire-Maia N. Genetic effects in Brazilian populations due to consanguineous marriages. Am J Med Genet [Internet]. 1990;35:115-7. Available from: http://www.ncbi.nlm.nih.gov/pubmed/2301460.

27. Freire-Maia N. Inbreeding in Brazil. Am J Hum Genet [Internet]. 1957;9:284-98. Available from: http://www.ncbi.nlm.nih.gov/pubmed/13497997. 
28. Weller M, Tanieri M, Pereira JC, Almeida EDS, Kok F, Santos S. Consanguineous unions and the burden of disability: a population-based study in communities of Northeastern Brazil. Am J Hum Biol [Internet]. 2012;24:835-40. Available from: http://www.ncbi.nlm.nih.gov/pubmed/23042425.

29. Cardoso-Dos-Santos AC, Ramallo V, Zagonel-Oliveira M, Veronez MR, Navarro P, Monlleó IL, et al. An invincible memory: what surname analysis tells us about history, health and population medical genetics in the Brazilian Northeast. J Biosoc Sci [Internet]. 2020;1-16. Available from: https://www.cambridge.org/core/product/identifier/S0021932020000127/type/journal_article.

30. Castro CCTdeS, Guaragna-Filho G, Calais FL, Coeli FB, Leal IRL, Cavalcante-Junior EF, et al. Clinical and molecular spectrum of patients with $17 \beta$-hydroxysteroid dehydrogenase type 3 (17- $\beta$-HSD3) deficiency. Arq Bras Endocrinol Metabol [Internet]. 2012;56:533-9. Available from: http://www.ncbi.nlm.nih.gov/pubmed/23295294.

31. Hartman AL, Hechtelt Jonker A, Parisi MA, Julkowska D, Lockhart N, Isasi R. Ethical, legal, and social issues (ELSI) in rare diseases: a landscape analysis from funders. Eur J Hum Genet [Internet]. Springer US; 2020;28:174-81. Available from: http://dx.doi.org/10.1038/s41431-019-0513-3.

32. Hanganu B, Manoilescu IS, Birlescu EA, Mocanu V, Hlescu AA, loan BG. Physician-patient relationship in rare diseases: an ethical approach. Arch Balk Med Union [Internet]. 2019;54:166-71. Available from: https://umbalk.org/physician-patient-relationship-in-rare-diseases-an-ethical-approach/.

33. Lee PA, Nordenström A, Houk CP, Ahmed SF, Auchus R, Baratz A, et al. Global Disorders of Sex Development Update since 2006: Perceptions, Approach and Care. Horm Res Paediatr [Internet]. 2016;85:158-80. Available from: https://www.karger.com/Article/FullText/442975.

34. Sudai M. Changing ethical and legal norms in the management of differences of sex development. Lancet Diabetes Endocrinol [Internet]. 2017;5:764-6. Available from: https://linkinghub.elsevier.com/retrieve/pii/S2213858717300438.

35. Greenberg JA. Legal, ethical, and human rights considerations for physicians treating children with atypical or ambiguous genitalia. Semin Perinatol [Internet]. Elsevier; 2017;41:252-5. Available from: http://dx.doi.org/10.1053/j.semperi.2017.03.012.

\section{Figures}




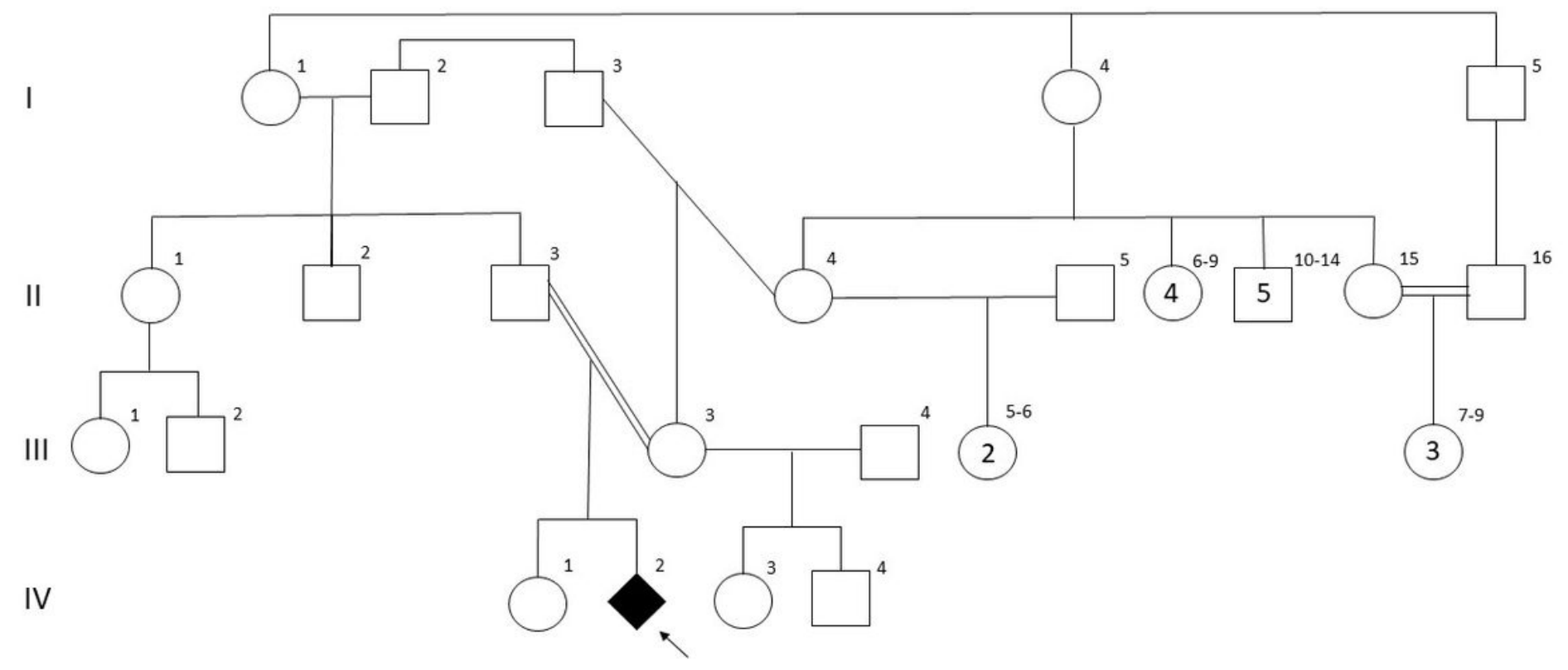

Figure 1

Family pedigree showing complex parental consanguinity. 

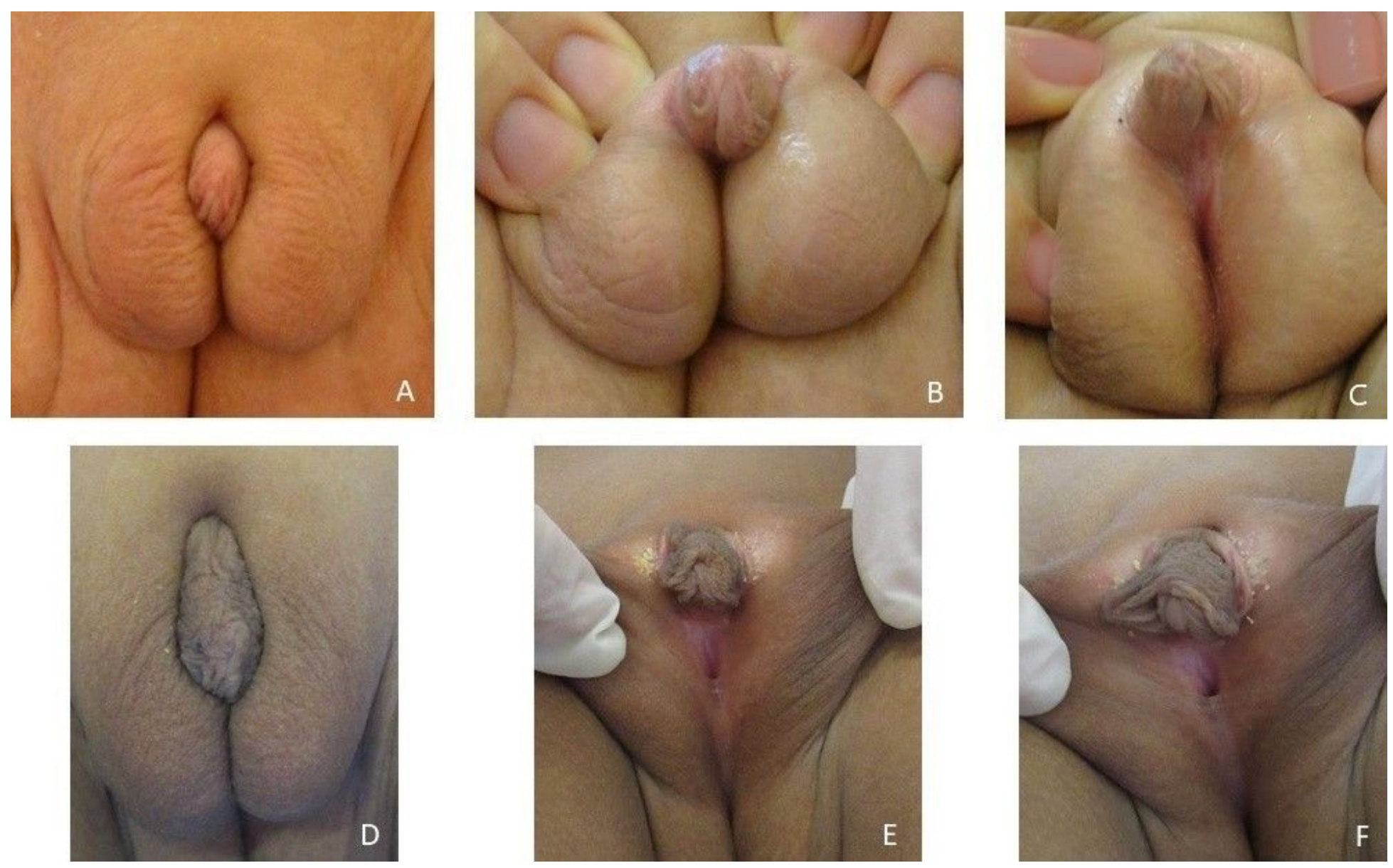

Figure 2
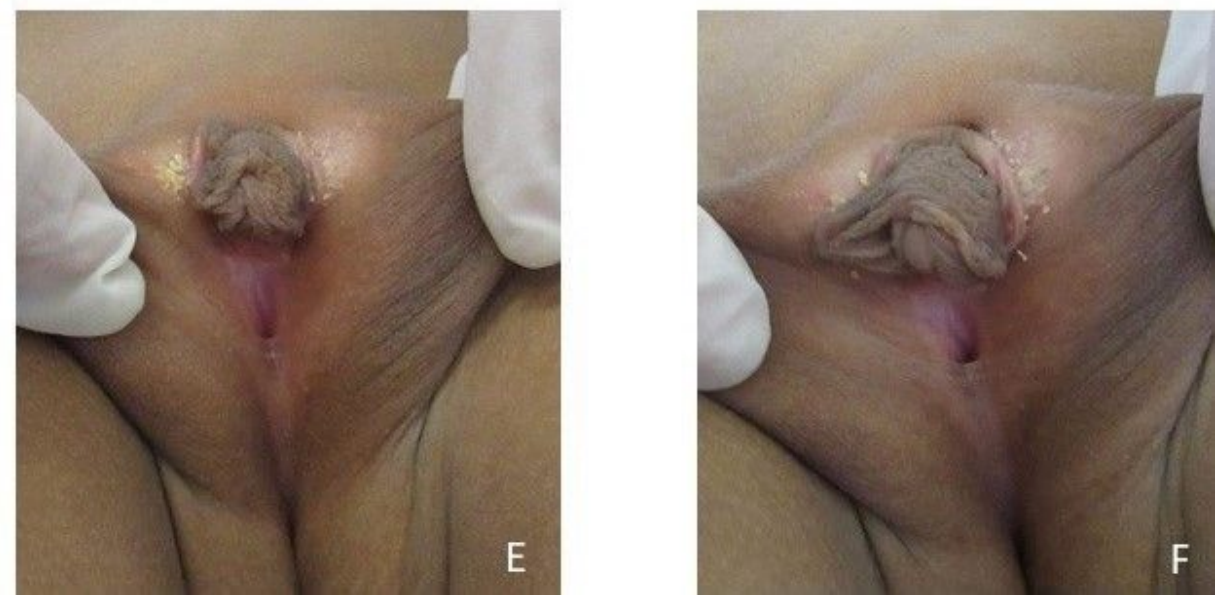

The external genitalia of our patient at 10 months $(A, B, C)$ and at 6 years old $(D, E, F)$.

\section{Supplementary Files}

This is a list of supplementary files associated with this preprint. Click to download.

- 12082021CAREchecklistEnglish2013.pdf

- Additionalfile1.docx

- Additionalfile2.docx

- Additionalfile3.docx

- Additionalfile4.docx 